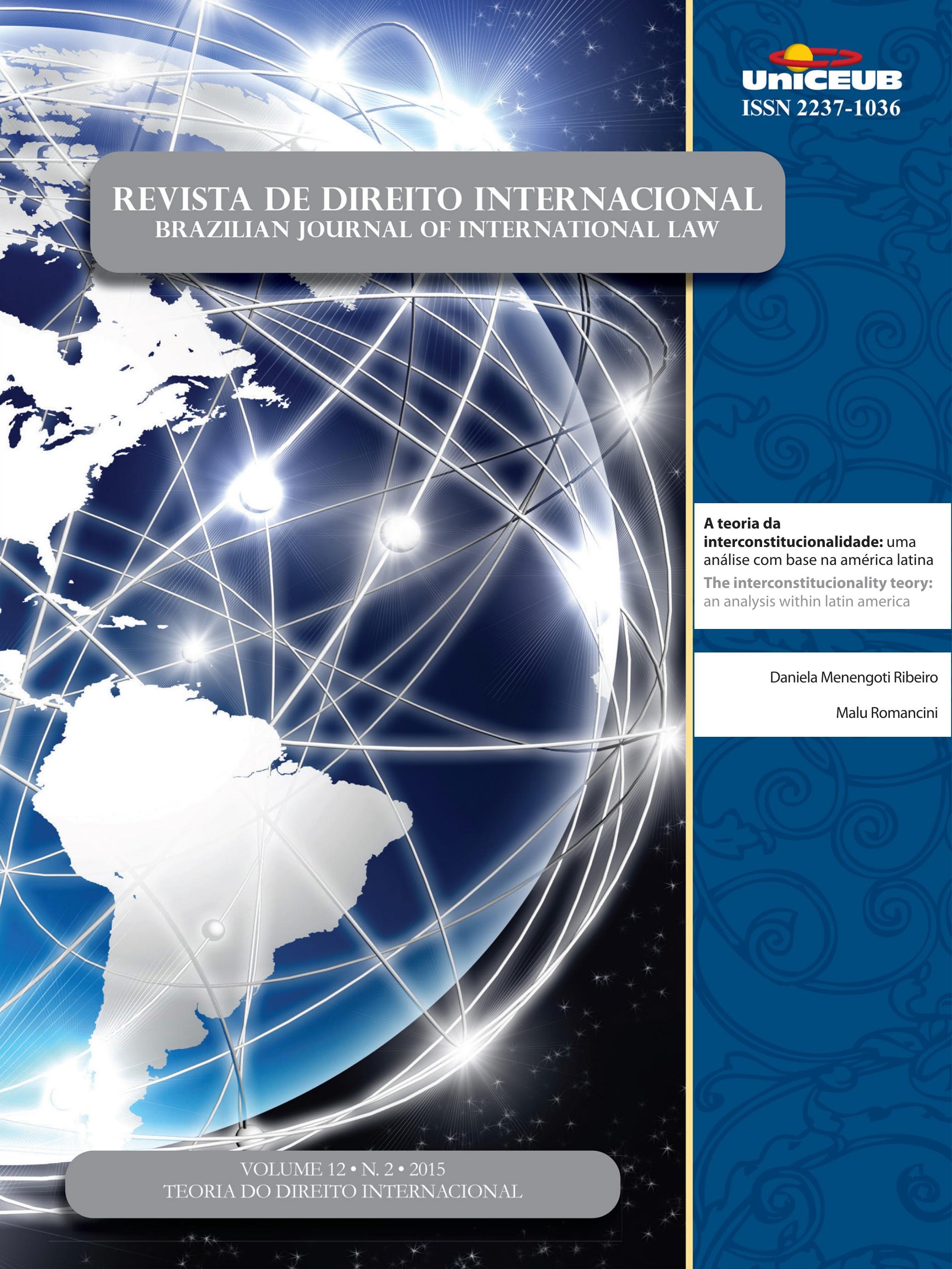




\section{Sumário}

CrôNiCAS DA ATUALIDADE do DiREITo INTERnACIONAL ..................................................... 2 Sarah Dayanna Lacerda Martins Lima, Carina Costa de Oliveira e Erika Braga

CrôniCas do Direito InternaCional dos InVESTIMENTOS ..............................................12 Nitish Monebhurrun

Por que voltar a Kelsen, o jurista do século XX ? 16 Inocêncio Mártires Coelho

O Princípio da Efetividade como conteúdo da norma fundamental (GrundNorm) DE KELSEN

Carlos Alberto Simões de Tomaz e Renata Mantovani de Lima

A JURIDIFICAÇÃo DE CONFLITOS POLÍTICOS NO DIREITO INTERNACIONAL PÚBLICO CONTEMPORÂ-

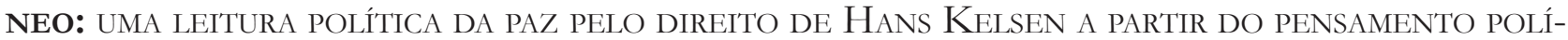
TICO De Claude Lefort

Arthur Roberto Capella Giannattasio

O SINCRETISMO TEÓRICO NA APROPRIAÇÃO DAS TEORIAS MONISTA E DUALISTA E SUA QUESTIONÁVEL UTILIDADE COMO CRITÉRIO PARA A CLASSIFICAÇÃO DO MODELO BRASILEIRO DE INCORPORA-

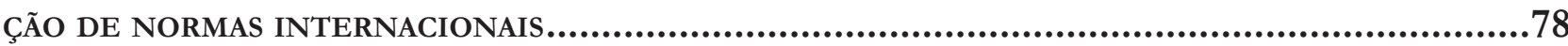
Breno Baía Magalhães

Direito Global em Pedaços: Fragmentação, Regimes e Pluralismo .98 Salem Hikmat Nasser

Por uma TeOria JURÍdica da INTEGRaÇão REgIONAL: A INTER-RELAÇÃO DiREITO INTERNO, DiREITO INTERNACIONAL PÚBLICO E DIREITO DA INTEGRAÇÃO Jamile Bergamaschine Mata Diz e Augusto Jaeger Júnior

A teOria DA INTERCONSTITUCIONALIDADE: UMA ANÁlISE COM BASE NA AMÉRICA LATINA...........160 Daniela Menengoti Ribeiro e Malu Romancini 
O DIÁLOGO HERMENÊUTICO E A PERGUNTA ADEQUADA À APLICAÇÃo DOS TRATADOS INTERNACIONAIS DE DIREITOS HUMANOS NO BRASIL: CAMINHOS PARA O PROCESSO DE INTERNACIONALIZAÇÃO

DA CONSTITUIÇÃO...................................................................................... 176

Rafael Fonseca Ferreira e Celine Barreto Anadon

O DIREITO COMPARADO NO STF: INTERNACIONALIZAÇÃO DA JURISDIÇÃO CONSTITUCIONAL BRASILEIRA

Carlos Bastide Horbach

THE PHILOSOPHY OF INTERNATIONAL LAW IN CONTEMPORARY SCHOLARSHIP: OVERCOMING NE-

GLIGENCE THROUGH THE GLOBAL EXPANSION OF HUMAN RIGHTS

Fabrício Bertini Pasquot Polido, Lucas Costa dos Anjos e Vinícius Machado Calixto

OpORTUNIDADES E DESAFIOS DAS TWAIL NO CONTEXTO LATINO-AMERICANO A PARTIR DE PERSPECTIVAS DOS POVOS INDÍGENAS AO DIREITO INTERNACIONAL

Fernanda Cristina de Oliveira Franco

Por Que uma ANÁlise ECONÔMICA Do DIREITO INTERNACIONAL PÚBLICO? DESAFIOS E PERSPECTIVAS DO MÉTODO NO BRASII

Gustavo Ferreira Ribeiro e Jose Guilherme Moreno Caiado

ANÁliSE ECONÔMICA do DIREITO INTERNACIONAL .263 Michele Alessandra Hastreiter e Luís Alexandre Carta Winter

RACIONALIDADE ECONÔMICA E OS ACORDOS BILATERAIS DE INVESTIMENTO 284 Michele Alessandra Hastreiter e Luís Alexandre Carta Winter

LOOKING FOR A BRICS PERSPECTIVE ON INTERNATIONAL LAW .304 Gabriel Webber Ziero

A INFLUÊNCIA DO DIREITO DESPORTIVO TRANSNACIONAL NO ORDENAMENTO JURÍDICO BRASILEIRO: DA REPRODUÇÃO DE NORMAS À APLICAÇÃO DIRETA PELA JURISDIÇÃO ESTATAL.......................3324 Tiago Silveira de Faria

CONVENCIONALIZAÇÃo DO DIREITO CIVIL: A APLICAÇÃo DOS TRATADOS E CONVENÇÕES INTERNACIONAIS NO ÂMBITO DAS RELAÇÕES PRIVADAS . 
NATIONAL JUdGES AND COURTS AS INSTITUTIONS FOR GLOBAL ECONOMIC GOVERNANCE 356

Juízes e tribunais nacionais como instituições para a governança global 356 Camilla Capucio

Is Trade Governance Changing? 371 Alberto do Amaral Júnior

OS FUNDOS ABUTRES: MEROS PARTICIPANTES DO CENÁRIO INTERNACIONAL OU SUJEITOS PERANTE O DIREITO INTERNACIONAL? 384

Guilherme Berger Schmitt

SHAREHOLDER AGREEMENTS IN PUBLICLY TRADED COMPANIES: A COMPARISON BETWEEN THE

U.S. AND BRAZIL. 402 Helena Masullo

REgulaÇÃo DO INVESTIMENTO ESTRANGEIRO DIRETO NO BRASIL: DA RESISTÊNCIA AOS TRATADOS BILATERAIS DE INVESTIMENTO À EMERGÊNCIA DE UM NOVO MODELO REGULATÓRIO 421 Fabio Morosini e Ely Caetano Xavier Júnior

DA QUALIFICAÇÃo JURÍDiCA dAS Distintas FORMAS DE PRESTAÇão TECNOLÓGICA: BREVE ANÁLISE DO MARCO REGULATÓRIO INTERNACIONAL

Daniel Amin Ferraz

REDEFINING TERRORISM: THE DANGER OF MISUNDERSTANDING THE MODERN WORLD'S GRAVEST THREAT

Jennifer Breedon

As EXECUÇões SELETIVAS E A RESPONSABILIZAÇÃo DE AGENTES TERRORISTAS 485 Alexandre Guerreiro

INTERNATIONAL CRIMINALS AND THEIR VIRTUAL CURRENCIES: THE NEED FOR AN INTERNATIONAL EFFORT IN REGULATING VIRTUAL CURRENCIES AND COMBATING CYBER CRIME Joy Marie Virga

Criminalidad transnacional organizada en el Ámbito del MERCOSUR: ¿Hacia un Derecho Penal Regional?. .528 Nicolás Santiago Cordini e Mariano Javier Hoet 
RUMO À INTERNACIONALIZAÇÃo DA PROTEÇÃO PENAL DO MEIO AMBIENTE: DOS ECOCRIMES AO ECOCÍDIO

Kathia Martin-Chenut, Laurent Neyret e Camila Perruso

Engaging the U.N. Guiding Principles on Business and Human Rights: the inter-AMERICAN COMMISSION ON HUMAN RIGHTS \& THE EXTRACTIVE SECTOR 571 Cindy S. Woods

O DIREITO HUMANO À COMUNICAÇÃo PRÉVIA E PORMENORIZADA DAS ACUSAÇÕES NOS PROCESSOS administrativos: O desprezo do Superior Tribunal de Justiça ao Pacto de San José da Costa Rica e À Corte Interamericana de Direitos Humanos .590

Daniel Wunder Hachem e Eloi Pethechust

A responsabilidade internacional do Brasil em FaCe do CONTRole de ConVENCionaliDADE EM SEDE DE DIREITOS HUMANOS: CONFLITO DE INTERPRETAÇÃO ENTRE A JURISDIÇÃO DA Corte Interamericana de Direitos Humanos e o Supremo Tribunal Federal quanto a LEI DE ANISTIA 612

Carla Ribeiro Volpini Silva e Bruno Wanderley Junior

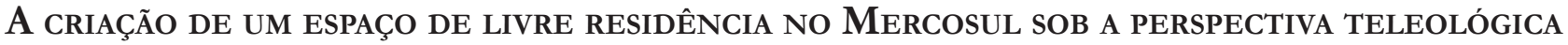
DA INTEGRAÇÃo REGIONAL: ASPECTOS NORMATIVOS E SOCIAIS DOS ACORDOS DE RESIDÊNCIA ....... 631

Aline Beltrame de Moura

A funcionalização como tendênCia evolutiva do Direito Internacional e sua conTRIBUIÇÃO AO REGIME LEGAL DO BANCO DE DADOS DE IDENTIFICAÇÃO DE PERFIL GENÉTICO NO BRASIL

Antonio Henrique Graciano Suxberger

O DIREITO INTERNACIONAL E A PROTEÇÃO DOS DIREITOS DE CRIANÇAS E DE ADOLESCENTES EM CONFLITO COM A LEI EM MOÇAMBIQUE

Bernardo Fernando Sicoche

ObTenÇão de PRovas no EXTERIOR: PARA ALÉM dA LEX FORI E LEX DiLigENTIAE. .685 André De Carvalho Ramos 
A Slight Revenge and a Growing Hope for Mauritius and the Chagossians: The UNClos Arbitral Tribunal's Award of 18 March 2015 on Chagos Marine Protected Area (Mauritius v. United Kingdom)

Géraldine Giraudeau

ANÁLISE DA RESPONSABILIDADE INTERNACIONAL DA UCRÂNIA POR VIOLAÇÃo DOS DIREITOS HUmanos na QUeda do voo da Malaysia Airlines (MH17). .728

Daniela Copetti Cravo

NatureZa JURÍdica do DESENVOLVIMENTO SUSTENTÁVEL No DIREITO INTERNACIONAL ........739 Pedro Ivo Diniz

A INFLUÊNCIA Da SOFT LAW NA FORMaÇão do DiREITo AMBIENTAL .767 Leonardo da Rocha de Souza e Margareth Anne Leister

As COMPLICADAS INTER-RELAÇÕES ENTRE OS SISTEMAS INTERNOS E INTERNACIONAIS DE PROTEÇãO DO DIREITO AO MEIO AMBIENTE SADIO. 785 José Adércio Leite Sampaio e Beatriz Souza Costa 


\title{
A teoria da interconstitucionalidade: uma análise com base na américa latina*
}

\section{The interconstitucionality teory: an analysis within latin america}

\author{
Daniela Menengoti Ribeiro** \\ Malu Romancini***
}

** Daniela M. Ribeiro é Professora do Programa de Mestrado em Ciências Jurídicas, graduação em Direito e Especialização EAD da Unicesumar. Pesquisadora da FUNADESP. Coordenadora/Líder do Grupo de Pesquisas (CNPq) "Internacionalização do direito: dilemas constitucionais e internacionais contemporâneos". Doutora em Direito-Relações Econômicas Internacionais pela Pontifícia Universidade Católica de São Paulo (PUC/SP) com período de pesquisa (doutorado sanduíche) na Université Paris 1 - Panthéon-Sorbonne, França. Mestre em Direito-Relações Internacionais, pela Universidade Federal de Santa Catarina (UFSC), com período de pesquisa no Mestrado em Integrazione Europea da Università Degli Studi Padova, Itália. Bolsista CNPq no mestrado e no doutorado. Especialista em Comercio Internacional y Inversiones, pela Universidad de Buenos Aires (UBA), Argentina. Especialista em Direito e Negócios Internacionais pela Universidade Federal de Santa Catarina (USFC).

*** Malu Romancini é Mestre em Direitos da Personalidade pela Unicesumar - Centro Universitário de Maringá-PR (2014-2015). Pósgraduada em Direito do Estado, com ênfase em Direito Constitucional, pela Universidade Estadual de Londrina (2013-2014). Bacharel em Direito pela Faculdade Maringá (2012). Bacharel em Secretariado Executivo Trilíngue pela Universidade Estadual de Maringá (2010). É advogada atuante, especialmente nas áreas de Direito Civil, Direito do Consumidor, Direito do Trabalho, Direito Empresarial, Direito Tributário, dentre outros. Atuou como professora de Direito Processual Civil na Fafiman Mandaguari (2014). Atualmente é professora de Direito Empresarial na Faculdade Alvorada, em Maringá (2015). Emails: daniela.mene ngoti@ gmail.com e maluromancini@gmail.com

\section{Resumo}

A presente pesquisa tem como objetivo estudar e compreender o fenômeno do interconstitucionalidade para demonstrar a efetividade dessa abordagem interconstitucional no âmbito da América Latina, o que se fará por meio de estudo de um caso julgado pela Corte Interamericana de Direitos Humanos. Utilizar-se-á o método dedutivo, instrumentos de pesquisa bibliográfica e análise jurisprudencial. Os resultados da pesquisa proposta neste artigo apontaram que a Teoria do Interconstitucionalidade, reconhecida inicialmente no sistema jurídico europeu, pode ser, também, identificada no contexto da América Latina, no âmbito do Sistema Interamericano de Direitos Humanos. Portanto, este artigo permitiu concluir que, em razão da conversação entre ordens jurídicas internacionais e da semelhança cultural, o interconstitucionalismo encontra alicerce para se desenvolver, e, ademais, permite maior proteção dos direitos dos indivíduos. O estudo do fenômeno do interconstitucionalismo em casos da Corte Interamericana de Direitos Humanos é inédito, cumprindo com seu caráter inovador e constituindo importante e rica fonte de informação com relevância acadêmica em razão da pujante internacionalização do direito, que implica na modificação da estrutura constitucional e na interação entre ordens jurídicas.

Palavras-chave: Interconstitucionalidade. América Latina. Corte Interamericana de Direitos Humanos.

\section{Abstract}

This research aims to study and understand the phenomenon of interconstitucionality to effectively demonstrate interconstitucional this approach in Latin America, which will be done through a case study judged by the Inter-American Court of Human Rights. It will use the deductive method, and instruments of literature research and jurisprudential analysis. The results of this research showed that the theory of interconstitucionality initially recognized only in the European legal system, can also be identified in the context of Latin America, in the inter-American Human Rights System. Therefore, this study concluded that because of the conversation between international legal systems and also cultural similarity, the interconstitucionalism finds ground to develop itself, and, moreover, allows greater protection of 
people's rights. The study of the interconstitucionalism in cases of the Inter-American Court of Human Rights is unprecedented, consisting the innovative character of this paper. Therefore, it constitutes an important and rich source of information with academic relevance due to the vigorous internationalization of law, which implies in the modification of constitutional structure and the interaction between legal systems.

Keywords: Interconstitucionalism. Latin America. Inter-American Court of Human Rights.

\section{INTRODUÇão}

A globalização e o consequente fortalecimento do direito internacional com o sentimento de mudança e troca de experiências que se instauraram no globo trouxeram uma evolução positiva considerável em relação aos direitos humanos e, dentro destes, os direitos da personalidade. Em razão disso, iniciou-se um processo de acentuada integração da sociedade mundial e, assim, os problemas relacionados aos direitos da personalidade - aqueles que são inerentes aos seres humanos tornaram-se impossíveis de ser amparados somente no âmbito doméstico dos Estados devido à importância de sua efetivação e tutela.

É nesse contexto que o direito constitucional inicia, assim, um processo de transformação desde o século passado, em que houve preocupação com os novos desafios de um direito que transcendeu as fronteiras dos Estados para diversas ordens jurídicas. Esse fenômeno foi denominado por por J. J. Canotilho como "interconstitucionalismo" que pode ser compreendido, de maneira breve, como a utilização de conversações constitucionais, bem como o estudo das relações interconstitucionais de concorrência, convergência, justaposição e conflitos de várias constituições e de vários poderes constituintes no mesmo espaço político.

É a partir dessa proposição que a presente pesquisa propõe-se a analisar se a Teoria Interconstitucionalidade proposta por Canotilho vem sendo utilizada no âmbito da Corte Interamericana de Direitos Humanos, como uma forma de fortalecimento e efetivação da tutela de problemas constitucionais envolvendo os direitos da personalidade.

Para tanto, o presente artigo busca analisar as ten- dências do Constitucionalismo global. Assim, abordar-se-á a mudança no Direito Constitucional tradicional e no Direito Internacional clássico, para tentar encontrar um direito intermediário, que melhor se encaixe com os problemas globais atuais.

Para tal, tratar-se-á da construção de um constitucionalismo global e da intensificação e da legitimação do interconstitucionalismo para a tutela dos direitos inerentes aos seres humanos. Por fim, dentro do mesmo tópico, será analisada a presença desse fenômeno na Europa - União Europeia - e - América Latina - Organização dos Estados Americanos.

A terceira e última parte deste estudo tratará da análise de um caso prático em que se percebe a presença do interconstitucionalismo no Sistema Interamericano de Direitos Humanos, a fim de demonstrar a sua ocorrência na América Latina.

\section{TendênCias do CONSTitucionalismo global}

O cenário que se instaurou ano mundo pós a Segunda Guerra fez com que a sociedade internacional buscasse um ambiente baseado na paz, na harmonia e na proteção mais efetiva dos direitos das pessoas. Com isso, surgiu a necessidade premente de cooperação internacional para alcançar interesses comuns, e neste contexto, começou a delinear-se um fenômeno, que posteriormente seria chamado de globalização.

Para Anthony Giddens, um dos primeiros autores a conceituar o termo,

[a] globalização, em suma, é uma complexa
variedade de processos, movidos por uma mistura
de influências políticas e econômicas. [...] Ela é
mais que o mero pano de fundo para políticas
contemporâneas: tomada como um todo, a
globalização está transformando as instituições das
sociedades em que vivemos. ${ }^{1}$

Essas mudanças provocaram o fortalecimento do direito internacional e trouxeram à tona o questionamento quanto o tradicional conceito de direito constitucional. Canotilho ${ }^{2}$ explica que a questão atual que

1 GIDDENS, Anthony. A terceira via: reflexões sobre o impasse político atual e o futuro da sociela-democracia. Tradução de Maria Luiza X. de A. Borges. Rio de Janeiro: Record, 2000, p. 43

2 CANOTILHO, J. J. Gomes. "Brancosos" e interconstitucionalidade: itinerários dos discursos sobre a historicidade constitucional. 2. ed. Almedina: Coimbra, 2008. p.190. 
se coloca à Constituição e ao direito constitucional é saber se pode-se continuar a considerar adequado um conceito de Constituição nos moldes de Luhmann, qual seja, pura e simplesmente como um horizonte de sentido dotado de instruções para uso suficiente de prática.

\section{Canotilho assevera que:}

[...] mesmo na era da globalização, o problema de constitucionalizar uma ordem política e econômica através do direito continua a residir na assimetria entre a "responsabilidade" imposta pelo Estado de direito democrático no plano político, social e econômico, e as suas reais capacidades de actuação, agora num contexto global crescentemente compressor da modelação jurídico-política estatal em matéria de segurança, de liberdade e do próprio direito ${ }^{3}$.

A tese de Luhmann é de que o conceito de Constituição é simplesmente uma reação à diferenciação entre direito e política, ou, em outras palavras, à total separação de ambos os sistemas de funções e à consequente necessidade de uma religação entre eles ${ }^{4}$. O que Luhmann faz, em poucas palavras, é separar o homem do sistema.

Ademais, Luhman afirma que a Constituição deve ser entendida como "[...] uma inovação de origem política no interior do próprio sistema do direito" ${ }^{5}$. O autor explica que pode haver confusão ao se pensar que, no passado, havia a ideia, apenas, de leis particularmente importantes e fundamentais, mas não a ideia de que houvesse uma lei que serviria de medida da conformi-

3 CANOTILHO, J. J. Gomes. "Brancosos" e interconstitucionalidade: itinerários dos discursos sobre a bistoricidade constitucional. 2. ed. Almedina: Coimbra, 2008. p. 22.

4 LUHMANN, Niklas. A constituição como Aquisição Evolutiva. Tradução realizada a partir do original ("Verfassung als evolutionäre Errungenschaft”. In: Rechthistorisches Journal . Vol. IX, 1990, pp. 176 a 220), cotejada com a tradução italiana de F. Fiore ("La costituzione come acquisizione evolutiva". In: ZAGREBELSKY, Gustavo. PORTINARO, Pier Paolo. LUTHER, Jörg. Il Futuro della Costituzione. Torino: Einaudi, 1996), por Menelick de Carvalho Netto, Giancarlo Corsi e Raffaele De Giorgi. Notas de rodapé traduzidas da versão em italiano por Paulo Sávio Peixoto Maia (texto não revisado pelo tradutor), p. 04.

5 LUHMANN, Niklas. A constituição como Aquisição Evolutiva. Tradução realizada a partir do original ("Verfassung als evolutionäre Errungenschaft". In: Rechthistorisches Journal . Vol. IX, 1990, pp. 176 a 220), cotejada com a tradução italiana de F. Fiore ("La costituzione come acquisizione evolutiva". In: ZAGREBELSKY, Gustavo. PORTINARO, Pier Paolo. LUTHER, Jörg. Il Futuro della Costituzione. Torino: Einaudi, 1996), por Menelick de Carvalho Netto, Giancarlo Corsi e Raffaele De Giorgi. Notas de rodapé traduzidas da versão em italiano por Paulo Sávio Peixoto Maia (texto não revisado pelo tradutor), p. 06. dade ou não conformidade ao direito de todas as outras leis e atos jurídicos. Essa posição particular, entretanto, somente adveio após a Declaração da Independência Americana de $1776^{6}$.

Nesse sentido, Canotilho afirma que o "[...] risco de a Constituição não estar em condições de continuar a ser compreendida como estatuto jurídico do político torna-se agora indisfarçável"’. E continua a explicar que"[...] mesmo que haja um Legal Transplant8 da ideia constitucional a nível global, nem por isso a Constituição poderá aspirar a ser mais do que é: um texto útil para direitos e políticas simbólicas".

Luigi Ferrajoli concorda que há um problema de salvaguarda dos direitos dos indivíduos a nível global, uma vez que, segundo ele, o mundo vive atualmente à mercê de um "vazio de direito público internacional":

a falta de uma esfera pública internacional no sentido aqui definido é a grande lacuna dramaticamente revelada pelas tragédias desses anos: pelas guerras, por tantos crimes contra a humanidade, pelo crescimento das desigualdades e pelas devastações ambientais. À crise dos Estados e, portanto, ao papel das esferas públicas nacionais, não correspondeu a construção de uma esfera pública à altura dos processos de globalização em curso. Faltam, ou são de todo débeis, não somente as garantias dos direitos solenemente proclamados, ou seja, a previsão de proibições e obrigações a eles correspondentes, mas também as instituições internacionais dedicadas às funções de garantia, quer dizer, à salvaguarda da paz, à mediação dos conflitos, à regulação do mercado e à tutela dos direitos e dos bens fundamentais de todos ${ }^{10}$.

6 LUHMANN, Niklas. A constituição como Aquisição Evolutiva. Tradução realizada a partir do original "Verfassung als evolutionäre Errungenschaft”. In: Rechthistorisches Journal . Vol. IX, 1990, pp. 176 a 220), cotejada com a tradução italiana de F. Fiore ("La costituzione come acquisizione evolutiva". In: ZAGREBELSKY, Gustavo. PORTINARO, Pier Paolo. LUTHER, Jörg. Il Futuro della Costituzione. Torino: Einaudi, 1996), por Menelick de Carvalho Netto, Giancarlo Corsi e Raffaele De Giorgi. Notas de rodapé traduzidas da versão em italiano por Paulo Sávio Peixoto Maia (texto não revisado pelo tradutor), p. 06.

7 CANOTILHO, J. J. Gomes. "Brancosos" e interconstitucionalidade: itinerários dos discursos sobre a historicidade constitucional. 2. ed. Almedina: Coimbra, 2008, p. 190.

8 Pode ser traduzido como um transplante legal/legitimado.

9 CANOTILHO, J. J. Gomes. "Brancosos" e interconstitucionalidade: itinerários dos discursos sobre a historicidade constitucional. 2. ed. Almedina: Coimbra, 2008, p. 190.

10 FERRAJOLI, Luigi. Democracia, estado de direito e jurisdição na crise do estado nacional. Disponível em: < file:///D:/PC\%20Malu/Pessoal/Mestrado/Disserta\%C3\%A7\%C3\%A3o/FERRAJOLI $\% 20$ DIREITO \%20DO\%20ESTADO\%202013.pdf>. Acesso em: 03 jun. 2015, p. 09. 
Pode-se notar a preocupação do autor quanto à questão da efetividade do direito internacional, de modo que difere-se do direito interno, principalmente porque este tem formas de imposição e possui coercibilidade, enquanto aquele funda-se na voluntariedade dos Estados. Em outras palavras, o direito interno dos Estados possui meios de coação, meios de ser respeitado e o direito internacional é uma jurisdição voluntária, isto é, os Estados não são obrigados a se submeterem às suas normas, a não ser que seja de sua livre vontade fazê-lo. E, uma vez submetidos à uma jurisdição internacional, o Estado fica vinculado e pode ser repreendido por meio de embargos econômicos, dentre outras sanções.

Nesse contexto, deve-se repensar a ordem internacional, em um cenário em que a globalização gerou efeitos tão significativos. O que se percebe é que o direito constitucional viu-se obrigado a andar conjuntamente com o direito internacional, conforme assevera Canotilho:

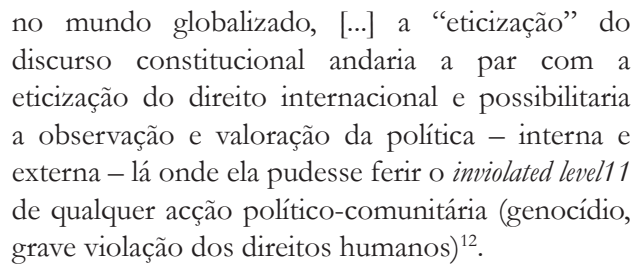
discurso constitucional andaria a par com a eticização do direito internacional e possibilitaria a observação e valoração da política - interna e externa - lá onde ela pudesse ferir o inviolated level11 de qualquer acção político-comunitária (genocídio, grave violação dos direitos humanos) ${ }^{12}$.

Diante dessa problemática, tentou-se conduzir este estudo de modo a encontrar uma solução para esse "vazio de direito público" ao qual se refere Ferrajoli. Primeiramente, deve-se modificar o direito constitucional, para o fim de que o constitucionalismo se adapte ao cenário jurídico global verificado atualmente. Canotilho afirma que as fronteiras entre o direito constitucional e o direito internacional estreitaram-se a tal ponto que hoje se trata do direito constitucional internacional e do direito internacional constitucional ${ }^{3}$.

Eis aqui a questão central deste estudo: como resolver esse problema? Diante da globalização e da modificação da condição da soberania estatal frente ao direito internacional, o interconstitucionalismo se mostra uma alternativa eficaz para o fim de tutelar os direitos dos cidadãos - em especial os direitos da personalidade - em um âmbito internacional?

11 Pode ser traduzido como nível inviolável das ações dos países. 12 CANOTILHO, J. J. Gomes. "Brancosos" e interconstitucionalidade: itinerários dos discursos sobre a historicidade constitucional. 2. ed. Almedina: Coimbra, 2008, p. 191-192.

13 CANOTILHO, J. J. Gomes. "Brancosos" e interconstitucionalidade: itinerários dos discursos sobre a historicidade constitucional. 2. ed. Almedina: Coimbra, 2008, p. 285.
A globalização e a fragmentação de interesses, a pluralização dos âmbitos sociais, o pluralismo das fontes do direito e a multiplicidade de formas de autoridades modificaram o conceito clássico de soberania. Para Ferrajoli, a matriz jusnaturalista do conceito embasou a concepção positivista do Estado e caracteriza um resquício do mundo jurídico pré-moderno. ${ }^{14}$

Nesse contexto, Duarte afirma que as transformações global ou comunitariamente (pela Comunidade/ União Europeia) impostas aos mecanismos estatais culminam em uma necessária reformulação a respeito do próprio conceito de Estado ${ }^{15}$.

Deve haver, conjuntamente, um reformulação das constituições dos Estados que deverão modificar-se no sentido de fornecer "[...] o conjunto de parâmetros básicos. Isso é o que se pensa em termos de Constituição, como um mecanismo capaz de lidar com os influxos gerados pela globalização" ${ }^{\prime 1}$.

Nesse sentido, Engelmann alerta que as Constituições deverão conter o conteúdo mínimo, ou seja, prever os parâmetros básicos, se tornando um mecanismo flexível para lidar com as inquietações que possam vir a aparecer no mundo globalizado ${ }^{17}$.

O que se percebe é que o Estado, mesmo que lhe sejam dadas atribuições, tem sua ação prejudicada no âmbito internacional, em um contexto globalmente interligado. Ferrajoli sustenta que, dessa forma, diminuem as possibilidades de controle dos Estados sobre a economia, sempre mais autônoma no mercado global ${ }^{18}$.

Canotilho, corroborando o pensamento de Ferrajoli,

14 Ver a respeito em: FERRAJOLI, Luigi. A soberania no mundo moderno: nascimento e crise do Estado nacional. Tradução de Carlo Coccioli e Márcio Lauria Filho. Revisão da tradução de Karina Jannini. 2. ed. São Paulo: Martins Fontes, 2007.

15 DUARTE, Écio Oto Ramos. Entre constitucionalismo cosmopolita e pluriversalismo internacional: neoconstitucionalismo e ordem mundial. Rio de Janeiro: Lumen Juris, 2014, p. 16.

16 DUARTE, Écio Oto Ramos. Entre constitucionalismo cosmopolita e pluriversalismo internacional: neoconstitucionalismo e ordem mundial. Rio de Janeiro: Lumen Juris, 2014, p. 120.

17 ENGELMANN, Wilson. A crise constitucional: a linguagem e os direitos humanos como condição de possibilidade para preservar o papel da Constituição no mundo globalizado. In: MORAIS, José Luis Bolzan de (Org.) O Estado e suas crises. Porto Alegre: Livraria do Advogado, 2005, p. 242.

18 FERRAJOLI, Luigi. Democracia, estado de direito e jurisdição na crise do estado nacional. Disponível em: <file:///D:/PC\%20Malu/Pessoal/Mestrado/Disserta\%C3\%A7\%C3\%A3o/FERRAJOLI $\% 20$ DIREITO \%20DO\%20ESTADO\%202013.pdf>. Acesso em: 03 jun. 2015, p. 05. 
assevera que o Estado tornou-se um "herói local", uma vez que

[...] quem quiser compreender o lugar e o sentido da Constituição terá de apelar para um patriotismo constitucional de inclusividade. Isso significa uma Constituição aberta a outros espaços, aberta a outras pessoas, aberta a outras normas, aberta a conflitos e consensos, aberta à sobreposição experiencial de consensos $^{19}$.

Nessa perspectiva, tratar-se-á da compreensão e da aplicação, na América Latina, da Teoria da Interconstitucionalidade, visando verificar a sua aplicabilidade para a proteção mais eficaz dos direitos dos cidadãos.

\section{A teoria DA INTERCONSTITUCIONALIDADE}

Inicialmente, é preciso compreender a proposta da análise desse fenômeno trazida por Canotilho, que se refere a um processo de construção do constitucionalismo europeu a ser estudado com base na Teoria de Interconstitucionalidade. Essa teoria, a princípio, estuda as relações interconstitucionais de concorrência, convergência, justaposição e conflitos de várias constituições e de vários poderes constituintes no mesmo espaço político ${ }^{20}$.

O constitucionalista português explica que a Teoria da Interconstitucionalidade já teve precedentes tanto na ordem jurídica medieval quanto na articulação da Constituição Federal em consonância com as constituições estatais $^{21}$.

No período medieval, podia se observar a convivência de diversas ordens jurídicas ao mesmo tempo em um só território ou região. Da mesma maneira, quando se observa a inter-relação entre as constituições estatais - de um Estado federativo - em detrimento da Constituição Federal, há um entrelaçamento, bem como uma justaposição entre ordens jurídicas - nesse caso, de ordem constitucional sobre ordem infraconstitucional.

Nesses Estados compostos, como é o caso do Brasil,

19 CANOTILHO, J. J. Gomes. "Brancosos" e interconstitucionalidade: itinerários dos discursos sobre a historicidade constitucional. 2. ed. Almedina: Coimbra, 2008. p.197.

20 CANOTILHO, J. J. Gomes. "Brancosos" e interconstitucionalidade: itinerários dos discursos sobre a historicidade constitucional. 2. ed. Almedina: Coimbra, 2008. p. 265-266.

21 CANOTILHO, J. J. Gomes. "Brancosos" e interconstitucionalidade: itinerários dos discursos sobre a bistoricidade constitucional. 2. ed. Almedina: Coimbra, 2008. p. 266. está sempre presente a articulação dos seguintes princípios: o princípio da sobreposição de ordens jurídicas ${ }^{22}$, o princípio da autonomia das unidades integrantes ${ }^{23}$ e o princípio da participação24 no poder central ${ }^{25}$.

Assim, pode-se afirmar que fenômeno do interconstitucionalismo teve suas origens nos ordenamentos medievais. No entanto, o interconstitucionalismo, que se trata neste estudo, é aquele que se percebe nos moldes atuais de concorrência, convergência e conflitos entre diversos poderes constituintes convivendo no mesmo espaço político.

A Teoria da Interconstitucionalidade enfrenta, dentre outros problemas, o da articulação entre constituições e da afirmação de poderes constituintes com fontes e legitimidades diversas ${ }^{26}$.

Para melhor entender esse fenômeno, é preciso estudar seus elementos básicos. O primeiro deles é a autodescrição, que significa dizer que "[...] autodescritivamente, os textos constitucionais nacionais conservam a memória e a identidade política e, quando inseridos numa rede interconstitucional, assumem-se sempre como autorreferência" ${ }^{27}$.

Em outras palavras, as constituições dos Estados não desaparecerão, mas sofrerão mudanças ao serem inseridas no contexto da rede interconstitucional. Isso porque o Estado deve "obedecer" as normativas internacionais, porém sem perder sua memória e identidade política.

Antonio Carlos Wolkmer defende a identidade cultural de uma região em suas constituições, a constituição não deve ser tão somente uma matriz
geradora de processos políticos, mas uma resultante
de correlações de forças e de lutas sociais em um
dado momento histórico do desenvolvimento da

22 No que diz respeito à sobreposição da ordem constitucional sobre a ordem infraconstitucional.

23 A autonomia das unidades integrantes é vislumbrada uma vez que os Estados podem elaborar suas constituições estatais.

24 E o princípio da participação do poder central se traduz em duas premissas: a primeira delas diz respeito à delegação de poder do poder central para os periféricos - no caso os Estados.

25 CANOTILHO, J. J. Gomes. "Brancosos” e interconstitucionalidade: itinerários dos discursos sobre a historicidade constitucional. 2. ed. Almedina: Coimbra, 2008. p. 266-267.

26 CANOTILHO, J. J. Gomes. "Brancosos" e interconstitucionalidade: itinerários dos discursos sobre a historicidade constitucional. 2. ed. Almedina: Coimbra, 2008, p. 267-268.

27 CANOTILHO, J. J. Gomes. "Brancosos" e interconstitucionalidade: itinerários dos discursos sobre a historicidade constitucional. 2. ed. Almedina: Coimbra, 2008. p. 269. 
sociedade. Enquanto pacto político que expressa a pluralidade, ela materializa uma forma de poder que se legitima pela convivência e coexistência de concepções divergentes, diversas e participativas ${ }^{28}$.

Para Peter Häberle, a Constituição deve ser concebida como cultural, pois não é somente um ordenamento jurídico voltado aos juristas, tampouco um mero texto jurídico, mas sim uma expressão de uma situação cultural e instrumento de autorrepresentação do povo ${ }^{29}$. Logo, a interpretação constitucional, sendo concebida como um produto cultural e aberto, deve pressupor um exercício de participação democrática ${ }^{30}$.

Esse caráter autodescritivo faz com que haja a manutenção do valor e da função das constituições estaduais. Canotilho explica esse processo por meio de uma metáfora, uma vez que afirma que as constituições dos Estados desceram do "castelo" para a "rede", mas não perderam as funções identificadoras pelo fato de, agora, estarem interligadas umas com as outras ${ }^{31}$.

Outra característica da interconstitucionalidade é o texto interorganizativo, o que implica a necessidade autodescritiva da organização superior, no caso europeu, da organização da União Europeia ${ }^{32}$.

Outros doutrinados, a exemplo de Mireille Delmas-Marty, estudam esse fenômeno de universalização das normas jurídicas denominado pela autora como "internacionalização dos direitos", cuja finalidade consiste em propor e analisar o fenômeno de aproximação dos sistemas jurídicos, mas não propriamente de sugerir uma unificação. ${ }^{33}$

28 WOLKMER, Antonio Carlos. Pluralismo crítico e perspectivas para um novo constitucionalismo na América Latina. In: WOLKMER, Antonio Carlos; MELO, Milena Petters. (Orgs.). Constitucionalismo latino-americano: tendências contemporâneas. Curitiba: Juruá, 2013, p. 19.

29 HÄBERLE, Peter; HABERMAS; Jürgen; FERRAJOLI, Luigi. VITALE, Ermanno. La constitucionalización de Europa. México: Instituto de Investigaciones Jurídicas de la UNAM, 2004. p. 25.

30 LEAL, Mônia Clarissa Hennig. La noción de constitución abierta de peter haberle como fundamento de una jurisdicción constitucional abierta y como presupuesto para la intervención del amicus curiae en el derecho brasileño. In: Estudios Constitucionales, Año 8, $\mathrm{N}^{\mathrm{o}}$ 1, 2010 , pp. 283 - 304.

31 CANOTILHO, J. J. Gomes. "Brancosos" e interconstitucionalidade: itinerários dos discursos sobre a historicidade constitucional. 2. ed. Almedina: Coimbra, 2008, p. 269.

32 CANOTILHO, J. J. Gomes. "Brancosos" e interconstitucionalidade: itinerários dos discursos sobre a historicidade constitucional. 2. ed. Almedina: Coimbra, 2008, p. 270.

33 Ver a respeito em: DELMAS-MARTY, Mireille. Les forces imaginantes $d u$ droit: le relaatif et l'universel. Paris, França: Seuil, 2004.
Também o constitucionalista alemão Peter Häberle afirma que "[...] hoje o Estado Constitucional e o Direito Internacional transformam-se em conjunto. $\mathrm{O}$ Direito constitucional não começa onde cessa o Direito Internacional". E continua sustentando também o “[...] contrário, ou seja, o Direito Internacional não termina onde começa o Direito Constitucional.”34

Porém, em contrapartida à interconstitucionalidade, o transconstitucionalismo teorizado por Marcelo Neves é a que mais se enquadra, no âmbito da América Latina, de paradigma à teoria apresentada por Canotilho. $\mathrm{O}$ transconstitucionalismo é caracterizado como uma relação transversal permanente entre ordens jurídicas em torno de problemas constitucionais comuns, como é o caso das questões que envolvem os direitos fundamentais e direitos humanos, por exemplo ${ }^{35}$.

O viés transconstitucionalista de Neves importa na relação de complementaridade entre as inúmeras ordens jurídicas existentes por meio da relação entre identidade e alteridade, no momento em que procuram reconstruir sua identidade por meio do entrelaçamento transconstitucional e rearticular com base na alteridade.

Nesse sentido, Neves fala em "conversação" ou "diálogo" entre Cortes, que podem ser vislumbrados em vários níveis, como por exemplo, o diálogo entre o Tribunal de Justiça das Comunidades Europeias (supranacional) e os Tribunais dos Estados-membros.

Neves aponta que a peculiaridade do transconstitucionalismo é o fato de o autor não abordar somente o entrelaçamento jurídico, mas também o fato de as ordens jurídicas se entrelaçarem no plano reflexivo de suas estruturas normativas, não havendo que se falar em hierarquia entre elas. Além disso, ele afirma que o fenômeno faz emergir uma "fertilização constitucional cruzada", isto é, as cortes passam a citar-se, não como precedentes, mas como autoridade persuasiva. Sendo assim, o que ocorre é um diálogo constitucional de aprendizagem recíproca ${ }^{36}$.

Portanto, o que caracteriza o transconstitucionalismo é o entrelaçamento de ordenamentos e normativas de órgãos internacionais, órgãos transnacionais, versus

34 HÄBERLE, Peter. Estado constitucional cooperativo. Rio de Janeiro: Renovar, 2007, pp. 11 - 12

35 NEVES, Marcelo. Transconstitucionalismo. São Paulo: Martins Fontes, 2013, p. XXI.

36 NEVES, Marcelo. Transconstitucionalismo. São Paulo: Martins Fontes, 2013, p. 118-119. 
tribunais internos dos Estados, dentre outros. O que se espera é um diálogo entre as ordens constitucionais conflitantes, por meio das chamadas pontes de transição, para o fim de que ambas troquem conhecimentos e citem-se umas às outras como forma de precedentes.

Assim, tendo comparado as principais características do interconstitucionalismo, bem como do transconstitucionalismo, parece correto afirmar que o fenômeno do interconstitucionalismo se mostra como uma alternativa mais adequada, em um cenário em que "[...] as decisões dos Estados têm cada vez mais efeitos extraterritoriais, em virtude das interdependências globais. Consequentemente, acabam por vincular, de forma crescente, pessoas diferentes daquelas que participaram na recolha dos titulares da decisão" 37 .

Isso porque, a ideia central é demonstrar que, o que se apresenta viável é a apreciação do interconstitucionalismo, fenômeno visível nos ordenamentos jurídicos, em razão do entrelaçamento de ordenamentos por causa da globalização e do fortalecimento do direito internacional.

Corroborando esse pensamento, preceitua Canotilho que

[...] claramente se compreendeu que uma sociedade funcionalmente diferenciada é também uma sociedade de organização e das organizações. Ora, as organizações atuam como actores corporativos. [...] Neste contexto, mantêm-se as pretensões de direção do Estado. Mas, com uma grande diferença: em vez do velho "estado heroico", hierarquicamente intervencionista, deve erguer-se o "Estado pós-heróico" - o Estado supervisor que, através de uma direção contextualizada (ou seja, através de uma autovinculação), proporciona, mas não determina, as convenções-quadro para a prossecução do bem comum ${ }^{38}$.

O que o autor português quis dizer é que o Estado deve mudar de figura nessa sociedade internacional, se levantando simplesmente como o supervisor e determinando mormente as normas padrões para sua sociedade.

No entanto, ao se tratar da Teoria da Interconstitucionalidade, tem-se que esta não se resume a um pro-

37 CANOTILHO, J. J. Gomes. "Brancosos" e interconstitucionalidade: itinerários dos discursos sobre a bistoricidade constitucional. 2. ed. Almedina: Coimbra, 2008. p. 291.

38 CANOTILHO, J. J. Gomes. "Brancosos" e interconstitucionalidade: itinerários dos discursos sobre a historicidade constitucional. 2. ed. Almedina: Coimbra, 2008. p. 147-148. blema de interorganizatividade entre os Estados. Ela é também uma Teoria de Interculturalidade Constitucionaß ${ }^{39}$.

Por interculturalidade entende-se como o conjunto de propostas de convivência democrática entre diferentes culturas, visando à integração entre elas sem anular sua diversidade, pelo contrário, essa proposta incentiva o potencial criativo e vital resultante da relações entre diferentes agentes e seus respectivos contextos ${ }^{40}$.

O próprio artigo 98 da Constituição boliviana de 2009 define interculturalidade, ao afirmar que a diversidade cultural constitui a base essencial do Estado Plurinacional Comunitário e que a "[...] interculturalidade é o instrumento para a coesão e a convivência harmônica e equilibrada entre todos os povos e nações. Assim, a interculturalidade terá lugar com respeito às diferenças e na igualdade de condições" ${ }^{\prime 4}$.

Vasconcelos esclarece que "[...] a questão da interculturalidade ultrapassou os limites dos países hegemônicos a partir do final do Século XX com o crescimento dos processos globalizadores mercantis operados por instituições transnacionais e a diminuição do poder dos estados-nações" ${ }^{42}$.

A interculturalidade jurídica pode ser conceituada como a convivência democrática de diversas ordens constitucionais, desde que permaneçam suas características básicas e sua essência. Assim, dentro do aspecto da cultura, ao se interligar com a Teoria do Interconstitucionalismo, surge a interculturalidade comunitária, que consiste nessa convivência de culturas em uma comunidade ou região. Porém, essa rede de interconstitucio-

39 CANOTILHO, J. J. Gomes. "Brancosos" e interconstitucionalidade: itinerários dos discursos sobre a bistoricidade constitucional. 2. ed. Almedina: Coimbra, 2008. p. 271.

40 FLEURI, Reinaldo Matias. In Palestra Proferida no V Colóquio Internacional Paulo Freire - 2005. Disponível em: <www.paulofreire.org.br/Textos/ fleuri_2005_recife_resumo_e_texto_completo.pdf $>$. Acesso em: 06 jun. 2015.

41 "Artículo 98. I. La diversidad cultural constituye la base esencial del Estado Plurinacional Comunitario. La interculturalidad es el instrumento para la cohesión y la convivencia armónica y equilibrada entre todos los pueblos y naciones. La interculturalidad tendrá lugar con respeto a las diferencias y en igualdad de condiciones. II. El Estado asumirá como fortaleza la existencia de culturas indigena originario campesinas, depositarias de saberes, conocimientos, valores, espiritualidades y cosmovisiones. III. Será responsabilidad fundamental del Estado preservar, desarrollar, proteger y difundir las culturas existentes en el país." Constituição Federal da Bolívia. Artigo 98. Disponível em: $<$ http://pdba.georgetown.edu/Constitutions/Bolivia/bolivia09. html>. Acesso em: 17 jun. 2015.

42 VASCONCELOS, Luciana Machado de. Interculturalidade. Disponível em: <http://www.cult.ufba.br/maisdefinicoes/INTERCULTURALIDADE.pdf>. Acesso em: 08 jun. 2015. p. 02. 
nalidade enfrenta um problema complexo, que se traduz na articulação de paradigmas de diversos de poderes constituintes ${ }^{43}$.

A interconstitucionalidade sugere, ainda, intersemioticidade, no sentido de que esse fenômeno se preocupa, também, com a investigação e descoberta de um conjunto de regras respeitantes à produção e interpretação dos textos constitucionais dos Estados e dos respectivos discursos e práticas sociais com elas relacionados. Assim, se pode afirmar, que as Constituições nacionais são dimensões relevantes de uma bermenêutica jurídica europeia ${ }^{44}$.

Percebe-se, com essa observação de Canotilho, que a interconstitucionalidade permite a manutenção da identidade dos Estados e que suas constituições não agirão mais de forma isolada, mas sim farão parte de um sistema de hermenêutica jurídica europeia.

Nesse contexto, assevera Canotilho que a interconstitucionalidade e a interculturalidade abrem espaço para o pluralismo de intérpretes, aberto e racionalmente crítico ${ }^{45}$. Nesse sentido, o interconstitucionalismo pareceu um fenômeno de aplicabilidade não somente no contexto europeu, mas em toda a perspectiva global atual.

\section{O FENÔMENO DO INTERCONSTITUCIONALISMO E suas razões de existir na América Latina}

A partir desse momento da pesquisa, passa-se a estudar se há a presença do fenômeno do interconstitucionalismo no âmbito da América Latina. Primeiramente, em razão da identidade cultural e da existência de pontos de convergência dentre os ordenamentos constitucionais dos Estados e, posteriormente, em razão da existência de um Sistema Interamericano de Direitos Humanos que possui jurisdição sobre os Estados latino-americanos.

A América Latina como um todo construiu sua his-

43 CANOTILHO, J. J. Gomes. "Brancosos" e interconstitucionalidade: itinerários dos discursos sobre a historicidade constitucional. 2. ed. Almedina: Coimbra, 2008, p. 275.

44 CANOTILHO, J. J. Gomes. "Brancosos" e interconstitucionalidade: itinerários dos discursos sobre a bistoricidade constitucional. 2. ed. Almedina: Coimbra, 2008, p. 277.

45 CANOTILHO, J. J. Gomes. "Brancosos" e interconstitucionalidade: itinerários dos discursos sobre a bistoricidade constitucional. 2. ed. Almedina: Coimbra, 2008, p. 279. tória com identidades culturais, uma vez que os Estados foram colonizados por espanhóis ou portugueses. Além disso, todos os Estados são historicamente recentes, em comparação com a Europa, e muitos tiveram regimes ditatoriais que perduraram até meados dos anos $60 \mathrm{ou}$ mais.

Acerca do que significa identidade cultural, Renato Seixas preceitua:

a identidade cultural é formada com diferentes
elementos culturais que podem ter distintos
significados intertextuais para cada indivíduo ou
grupo social. São elementos culturais os valores
sociais e os modos de pensar, os costumes e o
estilo de vida, as instituições, a história comum,
os grupos étnicos, o meio ambiente natural e
cultural, os pressupostos filosóficos subjacentes
às relações sociais e outros elementos a que certa
sociedade atribui significados culturais intertextuais
específicos. Com base em elementos como esses, o
indivíduo e o grupo social formam a convicção de
que compartilham uma cultura ${ }^{46}$.

Maria Luisa Ortiz Alvarez afirma que falar acerca de identidade latino-americana implica

\section{[...] remontar à época colonial e traçar uma trajetória que se estende até os dias atuais, observando como os diferentes períodos históricos operaram a re- significação do termo, a partir da conservação de determinados traços e da negociação, exclusão e inclusão de outros. $O$ encontro entre europeus e índios, povos portadores de culturas díspares, até antagônicas em certos aspectos, é tido como o momento inicial das transformações que conduziram à ideia de um "modo latino-americano de ser" ${ }^{\prime \prime 7}$.}

Percebe-se que, à época da colonização, os povos colonizados absorveram quase totalmente a cultura europeia colonizadora, diferenciando-se a América Central, que absorveu mais a cultura americana da América do Sul, que integralizou a cultura ocidental, advinda dos europeus.

Nesse contexto, é necessário trazer a importância da figura de Simón Bolívar, que mostrou-se um dos principais articuladores dos processos de independência e de pós-independência. Ademais, foi notória sua contri-

46 SEIXAS, Renato. Identidade Cultural da América Latina: conflitos culturais globais e mediação simbólica. Disponível em: < http://www.usp. br/prolam/downloads/2008_1_4.pdf >. Acesso dia: 16/07/2015, p. 98.

47 ALVAREZ, Maria Luisa Ortiz. (Des) construção da identidade latino-americana: heranças do passado e desafios futuros. Disponível em: $<$ http://unb.revistaintercambio.net.br/24h/pessoa/temp/anexo/1/231/427.pdf>. Acesso em: 16 jul. 2015, p. 02. 
buição para construir uma identidade entre os Estados latino-americanos.

Entretanto, conforme expõe Alvarez, esse ideário pretendia ir mais além, à medida que Bolívar manifestava seu sonho de ver a América unida em uma só nação, que teria um só governo que confederaria todos os diferentes Estados da região ${ }^{48}$.

Apesar de suas ideias revolucionárias não terem encontrado efetivação na América Latina, Bolívar influenciou o "modo latino-americano de ser", inclusive, tendo seu nome incluído em diversas constituições dos Estados latino-americanos, ditas constituições Bolivarianas, como a da Venezuela e do Equador.

Quanto ao contexto histórico da região, Flávia Piovesan destaca a existência dos regimes ditatoriais e da transição política de tais regimes à democracia. O primeiro período foi marcado por inúmeras violações de direitos e liberdades, e o segundo período caracterizou-se pela tentativa de consolidar o efetivo respeito aos direitos humanos ${ }^{49}$.

Como consequência disso, após a caída dos regimes ditatoriais, as constituições passaram a se abrirem para incorporaram o novo comunitarismo internacional, admitindo a celebração de tratados de integração entre Estados para conformar organizações supraestatais e interestatais.

Com o advento da Convenção Americana de Direitos Humanos em 1978, dos 11 Estados que ratificaram a Convenção na época, menos da metade possuía governos eleitos de forma democrática. Assim, havia dificuldade para o Sistema Interamericano de Direitos Humanos em lidar com tal paradoxo: como proteger os direitos humanos em um espaço onde não havia inicialmente abertura para a tríade Democracia - Estado de Direito - Direitos Humanos ${ }^{50}$.

Nesse sentido, são notórias as semelhanças entre os Estados da América Latina, inclusive, porque refletem

48 ALVAREZ, Maria Luisa Ortiz. (Des) construção da identidade latino-americana: heranças do passado e desafios futuros. Disponível em: $<$ http://unb.revistaintercambio.net.br/24h/pessoa/temp/anexo/1/231/427.pdf>. Acesso em: 16 jul. 2015, p. 02.

49 PIOVESAN, Flavia. Direitos humanos e justiça internacional: um estudo comparativo dos sistemas regionais europeu, interamericano e africano. $2^{a}$ ed. São Paulo: Saraiva, 2011, p. 123-124.

50 PIOVESAN, Flavia. Direitos humanos e diálogo entre jurisdições. In: Revista Brasileira de Direito Constitucional - RBDC, n. 19, p. 67-93, jan-jun, 2012. uma integração quase que natural. Em outras palavras, ao se comparar a integração latino-americana com a integração europeia, percebe-se que há muito mais pontos de convergência no primeiro em detrimento do segundo. Isso porque os cidadãos latino-americanos se reconhecem uns nos outros, em sua cultura, em seu modo de viver, na variedade de nações dentro de um mesmo Estado. Assim, pode-se afirmar que, no que se refere à identidade e integração entre os Estados, a América Latina mostra-se bastante integrada.

Peter Häberle acredita que a Constituição deve ser concebida como cultural, pois não deve representar somente um ordenamento jurídico voltado aos juristas, mas sim traduzir uma situação cultural e servir como instrumento de autorrepresentação de seu povo ${ }^{51}$.

Assim, percebe-se que, hoje, as constituições dos Estados da América Latina, além de serem a expressão da cultura local e perfazerem-se como instrumento de autorrepresentação de seu povo, também estão em consonância. Em outras palavras, as constituições latino-americanas possuem diversos pontos de convergência.

A Teoria de Häberle transcendeu o continente europeu e chegou à América Latina com o intuito de ajudar o processo não somente de integração política, mas também cultural, buscando desenvolver a concepção de um "direito constitucional comum".

Nesse cenário, que a Teoria da Interconstitucionalidade ganha forma e razão de existir. Isso porque, segundo Canotilho, essa teoria estuda as relações interconstitucionais de concorrência, convergência, justaposição e conflitos de várias constituições e de vários poderes constituintes no mesmo espaço político ${ }^{52}$.

Em primeiro lugar, cumpre destacar que a interconstitucionalidade que se observa e se propõe com este estudo, no âmbito da América Latina, é diferente daquela que ocorre na Europa. Isso porque a Europa está inserida na União Europeia, que é uma organização internacional sui generis, sendo diferenciada de qualquer outra OI. Assim, observa-se na UE um sistema jurídico único - supranacional, de alta integração e imposto para todos os Estados membros.

51 HÄBERLE, Peter; HABERMAS; Jürgen; FERRAJOLI, Luigi. VITALE, Ermanno. La constitucionalización de Europa. México: Instituto de Investigaciones Jurídicas de la UNAM, 2004, p. 25.

52 CANOTILHO, J. J. Gomes. "Brancosos" e interconstitucionalidade: itinerários dos discursos sobre a historicidade constitucional. 2. ed. Almedina: Coimbra, 2008, p. 265-266. 
Por outro lado, na América Latina, tem-se a Organização dos Estados Americanos - uma organização internacional mais regular, ou seja, com características mais comuns às demais OI's. Em outras palavras, a OEA não possui um sistema jurídico próprio imposto a todos os membros. Tem-se, na verdade, a Convenção Americana de Direitos Humanos e dois órgãos que são responsáveis por fiscalizar, aplicar e fazer cumprir as suas determinações, quais sejam, a Corte e a Comissão Interamericana de Direitos Humanos.

Assim, a dinâmica da América Latina funciona da seguinte forma: os Estados membros da OEA, e que ratificaram a Convenção Americana, estão sujeitos às normas nela contidas. Dessa forma, estão também submetidos à jurisdição da Corte e da Comissão.

Nesse sentido, os Estados membros, bem como a CIDH podem submeter casos para serem julgados pela Corte IDH, desde que cumpridos os requisitos determinados pela legislação da OEA. Dentre os requisitos, pode-se mencionar o fato de terem se exaurido as vias internas do Estado, ou seja, o referido caso transitou em julgado e não há mais possibilidade de recorrer a quaisquer órgão superior do Estado membro - artigo 61.2 da Convenção $0^{53}$. Ademais, o caso deve versar sobre matéria objeto de proteção da Convenção, isto é, inerente a direitos humanos, pois esta é a competência da Corte $\mathrm{IDH}$ - conforme artigo 34 da Convenção ${ }^{54}$.

Nesse diapasão, a Corte IDH cumpre papel parecido com o do Tribunal de Justiça das Comunidades Europeias. Isso porque, quando um caso é submetido à análise e julgamento na Corte IDH, esta faz um controle de convencionalidade entre as leis do Estado membro que foram aplicadas no caso concreto e as normas contidas na Convenção, conforme preceitua o artigo 62.3 da Convenção ${ }^{55}$. Esse artigo dita que a Corte

53 "Artículo 61 1. Sólo los Estados Partes y la Comisión tienen derecho a someter un caso a la decisión de la Corte. 2. Para que la Corte pueda conocer de cualquier caso, es necesario que sean agotados los procedimientos previstos en los artículos 48 a 50." Disponível em: <http://www.oas.org/dil/ esp/tratados_B-32_Convencion_Americana_sobre_Derechos_Humanos.htm>. Acesso em: 17 jun. 2015.

54 "Artículo 34 La Comisión Interamericana de Derechos Humanos se compondrá de siete miembros, que deberán ser personas de alta autoridad moral y reconocida versación en materia de derechos humanos." Disponível em: $<$ http://www.oas.org/dil/esp/tratados_B-32_Convencion_Americana_sobre_Derechos_Humanos.htm>. Acesso em: 17 jun. 2015.

55 "Artículo 62 [...] 3. La Corte tiene competencia para conocer de cualquier caso relativo a la interpretación y aplicación de las disposiciones de esta Convención que le sea sometido, siempre que los Estados Partes en el caso hayan reconocido o reconozcan dicha competencia, ora por declaración especial, como se tem competência para conhecer qualquer caso relativo à interpretação e aplicação das disposições da Convenção Americana de Direitos Humanos que lhe seja submetido, sempre que os Estados partes no caso tenham reconhecido ou reconheçam dita competência, seja por declaração especial, seja por convenção especial.

Dessa forma, quando um Estado ou a CIDH submete algum caso para ser julgado pela Corte IDH, o interconstitucionalismo está de fato ocorrendo, o que se verifica por meio de três premissas.

Para que se possa compreender tais premissas, é necessário uma retrospectiva acerca do fenômeno do interconstitucionalismo. Conforme já explanado, a Teoria da Interconstitucionalidade, segundo Canotilho, estuda as relações interconstitucionais de concorrência, convergência, justaposição e conflitos de várias constituições e de vários poderes constituintes no mesmo espaço político ${ }^{56}$.

As relações de concorrência se dão no sentido de concomitância, convivência, simultaneidade, coexistência de ordens jurídicas. Por exemplo, na OEA há diversos Estados e cada um possui a sua ordem jurídica constitucional própria. Ademais, o próprio Sistema Interamericano de Direitos Humanos possui a sua ordem jurídica internacional própria. Assim, elas coexistem e se inter-relacionam.

No que se refere à convergência, tem-se no sentido de afinidade, identidade, concordância, coincidência, consonância, harmonia. Isso porque as constituições dos Estados da América Latina possuem diversos pontos de convergência, em razão da colonização e história semelhantes. Além disso, essas constituições devem estar em consonância e harmonia com a Convenção Americana dentro do SIDH.

As relações de justaposição traduzem-se no fato de que o SIDH, muitas vezes, sobrepõe a sua ordem jurídica aos ordenamentos constitucionais dos Estados membros. A legitimidade dessa ação ocorre mormente porque os Estados-membros assim o quiseram, quando aceitaram a jurisdição do SIDH.

No que se refere a relações de conflitos de várias

indica en los incisos anteriores, ora por convención especial." Disponível em: $<$ http://www.oas.org/dil/esp/tratados_B-32_Convencion_Americana_sobre_Derechos_Humanos.htm>. Acesso em: 17 jun. 2015.

56 CANOTILHO, J. J. Gomes. "Brancosos" e interconstitucionalidade: itinerários dos discursos sobre a bistoricidade constitucional. 2. ed. Almedina: Coimbra, 2008. p. 265-266. 
constituições e de vários poderes constituintes, tem-se que cada Estado membro tem sua Constituição e, mesmo que hajam pontos de convergência, cada um possui suas especificidades, direitos que tutelam mais ferozmente, e outros que se tutela de forma mais branda.

Explicadas tais relações, chega-se às três premissas que demonstram a presença do interconstitucionalismo na América Latina. A primeira delas diz respeito à relação de justaposição de ordens jurídicas, que ocorre justamente pelo fato do aceite por parte dos Estados membros da jurisdição do SIDH. Em outras palavras, no momento em que o Estado membro aceita fazer parte do SIDH, ele se submete às suas normas. Sendo assim, o ordenamento constitucional interno do Estado passa a não ser mais a última instância, mas sim o ordenamento internacional. Importante frisar que não se trata de mais uma instância recursal, mas de uma justaposição entre ordens jurídicas, na qual a ordem internacional se sobreporá à ordem interna. Também não se trata somente da imposição das decisões da Corte aos tribunais nacionais com competências constitucionais, mas também de revisão da jurisprudência dos Estados membros à luz das decisões da Corte.

A segunda premissa pela qual percebe-se a presença do interconstitucionalismo vai mais além do que uma "simples" justaposição. Essa premissa refere-se à aplicação de norma constitucional de Estado diverso daquele que é parte no processo ao caso concreto, semelhante ao que ocorre no sistema europeu. Para que se possa compreender tal situação, imagina-se que um caso ocorrido do Equador, envolvendo desrespeito aos direitos humanos dos indígenas, foi submetido a julgamento na Corte IDH. No decorrer do julgamento, os juízes da Corte IDH reparam que a legislação constitucional boliviana é mais protetiva com relação aos direitos dos indígenas. Assim, a Corte IDH aplica o direito constitucional boliviano ao caso equatoriano, mesmo que a Bolívia não seja parte desta lide.

Por fim, a terceira premissa diz respeito à utilização, por parte da Corte IDH, de jurisprudências de Cortes de Direitos Humanos que não fazem parte do sistema interamericano, como por exemplo, a Corte Europeia de Direitos Humanos, para fundamentar suas decisões.

Esses casos vêm sendo percebidos ultimamente quando da análise da jurisprudência da Corte IDH e traduzem claramente a presença do interconstitucionalismo no SIDH, visando conceder maior proteção aos direitos humanos dos indivíduos.

\section{O Caso 12.465 - Povo indígena Kichwa de Sarayaku Versus Equador e o intercons- TITUCIONALISMO LATINO-AMERICANO}

Analisar-se-á, nesta seção, um caso julgado pela Corte Interamericana de Direitos Humanos com a finalidade de confirmar a hipótese proposta por este estudo, qual seja, constatar a presença do fenômeno interconstitucionalismo no âmbito da América Latina. ${ }^{57}$

O caso n ${ }^{\circ} 12.465$ - PUEBLO INDÍGENA KICHWA DE SARAYAKU VS. ECUADOR referia-se principalmente à concessão de uma permissão por parte do Estado equatoriano dada a certa empresa petrolífera privada para realizar atividades de exploração petroleira no território do Povo Indígena Kichwa de Sarayaku, na década de 90 , sem que se houvesse consultado previamente tal povo e sem qualquer consentimento por parte da comunidade indígena. Assim, iniciaram-se as explorações e seus efeitos foram de tamanha monta que repercutiram em todo o mundo.

Dentre os efeitos desse ato, tem-se o risco de morte da população indígena, que ficou um período sem poder buscar meios de subsistência, além de ter seus direitos de circulação e de expressar sua cultura violados. Ademais, o dano ambiental causado pela empresa CGC resta inestimável, uma vez que utilizaram-se de explosivos de alto poder em vários pontos do território indígena, construíram portos, destruíram cavernas e fontes d'água nativas, rios subterrâneos utilizados pela comunidade para consumo próprio, além de derrubar incontáveis árvores e plantas de grande valor ambiental e de subsistência para os Kichwa ${ }^{58}$.

Nesse sentido, a CIDH apontou as possíveis violações por parte do Estado equatoriano, quais sejam, direito de consulta e propriedade indígena, direito de livre circulação, de expressão de sua cultura, direito ao

57 O Caso 12.051 - Karen Atala e filhas vs. Chile, que versa acerca do direito à livre orientação sexual, bem como direito à vida privada sem interferência, também revela a ocorrência do fenômeno do interconstitucionalismo. Nesse caso, a Corte Interamericana não realizou diálogos somente com a ordem constitucional dos Estados membros da OEA e que ratificaram o Pacto de San José da Costa Rica, mas também com a Corte Europeia de Direitos Humanos. 58 Informações extraídas da sentença da Corte IDH. CORTE INTERAMERICANA DE DIREITOS HUMANOS. CASO PUEBLO INDÍGENA KICHWA DE SARAYAKU VS. ECUADOR. SENTENCA DE 27 DE JUNHO DE 2012. Disponível em: $<$ http://www.corteidh.or.cr/docs/casos/articulos/seriec_245_esp. pdf $>$. Acesso em: 22 jun. 2015. 
meio ambiente, direito à vida e integridade física, direito à liberdade, direito à garantia e proteção judicial, dentre outros.

Dentre os direitos supracitados que foram violados, é claro que se encontram diversos direitos da personalidade. Os principais deles são o direito à vida e à integridade física, que, nesse caso, a Corte entendeu como violados porque o Estado violou seu dever de garantir o respeito ao direito de propriedade e, consequentemente, permitiu o uso de explosivos no território indígena, o que ocasionou uma situação permanente de perigo à vida e à sobrevivência desse povo. Ademais, colocou em risco o direito desse povo de preservar e transmitir seu legado cultural ${ }^{59}$.

Ao final, a Corte IDH concluiu que é obrigação do Estado garantir o direito à consulta prévia do povo indígena antes de conceder permissões para adentrar e explorar seu território. Como fundamentação dessa decisão, a Corte utilizou-se de jurisprudências de diversos países da América Latina, dentre eles Argentina, Bolívia, Chile, Colômbia, México, Nicarágua, Paraguai, Peru, Venezuela, Belize e Brasil.

Citou a Constituição Nacional da República Argentina, de 1994, que, em seu artigo 75.17, reconhece a preexistência étnica e cultural dos povos indígenas argentinos e das pessoas jurídicas de duas comunidades ${ }^{60}$.

Aduziu, também, que, na Bolívia, a Constituição Política do Estado, de 2009. Reconhece o direito dos povos indígenas a serem consultados mediante procedimentos apropriados quando houver medidas legislativas ou administrativas que os afetem, conforme disposição do artigo 30, II, 15. Ademais, o Tribunal Constitucional da Bolívia se pronunciou em diversas oportunidades acerca do direito à consulta prévia. No Chile, de forma semelhante, há lei própria para tutelar tais direitos - Lei 19.253 (Lei Indígena) ${ }^{61}$.

59 Informações extraídas da sentença da Corte IDH. CORTE INTERAMERICANA DE DIREITOS HUMANOS. CASO PUEBLO INDÍGENA KICHWA DE SARAYAKU VS. ECUADOR. SENTENCA DE 27 DE JUNHO DE 2012. Disponível em: $<$ http://www.corteidh.or.cr/docs/casos/articulos/seriec_245_esp. pdf $>$. Acesso em: 22 jun. 2015, p. 72-73.

60 Informações extraídas da sentença da Corte IDH. CORTE INTERAMERICANA DE DIREITOS HUMANOS. CASO PUEBLO INDÍGENA KICHWA DE SARAYAKU VS. ECUADOR. SENTENCA DE 27 DE JUNHO DE 2012. Disponível em: $<$ http://www.corteidh.or.cr/docs/casos/articulos/seriec_245_esp. pdf >. Acesso em: 22 jun. 2015, p. 45.

61 Informações extraídas da sentença da Corte IDH. CORTE
A Constituição Política da Colômbia, por sua vez, estabelece, no parágrafo do artigo 330, que a exploração dos recursos naturais em territórios indígenas não podem ser feitas de modo a desrespeitar a integridade cultural, social e econômica das comunidades. Ademais, a Corte valeu-se da interpretação da sentença T-129/11, parágrafo 5.1 proferida pela Corte Constitucional da Colômbia ao aduzir que é dever do Estado garantir e aplicar real e efetivamente o direito fundamental de consulta prévia das comunidades étnicas, pois diante disto, poderá se chegar a um ponto intermediário de diálogo intercultural no qual os povos possam exercer seu direito de autonomia frente aos modelos econômicos baseados na economia de mercado ${ }^{62}$.

A Constituição Mexicana igualmente dispõe que o Estado deve promover a igualdade de oportunidades dos indígenas e eliminar qualquer prática discriminatória $^{63}$.

De forma semelhante, a Constituição da Nicarágua positiva, no Título IV, artigo 89, que as comunidades indígenas têm direito a preservar e desenvolver sua identidade cultural na unidade nacional. Ademais, o Estado reconhece o gozo, uso e disfrute das águas e bosques pelas comunidades indígenas ${ }^{64}$.

A Constituição do Paraguai de 1992 estabelece, em seu artigo 64, que os povos indígenas têm direito à propriedade comunitária da terra, em extensão e qualidade suficientes para a conservação e desenvolvimento de suas formas peculiares de vida ${ }^{65}$.

INTERAMERICANA DE DIREITOS HUMANOS. CASO PUEBLO INDÍGENA KICHWA DE SARAYAKU VS. ECUADOR. SENTENCA DE 27 DE JUNHO DE 2012. Disponível em: $<$ http://www.corteidh.or.cr/docs/casos/articulos/seriec_245_esp. pdf >. Acesso em: 22 jun. 2015, p. 45.

62 CORTE INTERAMERICANA DE DIREITOS HUMANOS. CASO PUEBLO INDÍGENA KICHWA DE SARAYAKU VS. ECUADOR. SENTENCA DE 27 DE JUNHO DE 2012. Disponível em: <http://www.corteidh.or.cr/docs/casos/articulos/ seriec_245_esp.pdf>. Acesso em: 22 jun. 2015, p. 47, 56 e 58.

63 Informações extraídas da sentença da Corte IDH. CORTE INTERAMERICANA DE DIREITOS HUMANOS. CASO PUEBLO INDÍGENA KICHWA DE SARAYAKU VS. ECUADOR. SENTENCA DE 27 DE JUNHO DE 2012. Disponível em: $<$ http://www.corteidh.or.cr/docs/casos/articulos/seriec_245_esp. pdf>. Acesso em: 22 jun. 2015, p. 45.

64 Informações extraídas da sentença da Corte IDH. CORTE INTERAMERICANA DE DIREITOS HUMANOS. CASO PUEBLO INDÍGENA KICHWA DE SARAYAKU VS. ECUADOR. SENTENCA DE 27 DE JUNHO DE 2012. Disponível em: <http://www.corteidh.or.cr/docs/casos/articulos/seriec_245_esp. pdf>. Acesso em: 22 jun. 2015, p. 46.

65 Informações extraídas da sentença da Corte IDH. CORTE 
A Constituição Bolivariana da Venezuela, de 1999, também dispõe, em seu artigo 120, que o aproveitamento dos recursos naturais nos habitats indígenas por parte do Estado não podem lesionar a integridade cultural, social e econômica destes ${ }^{66}$.

A Corte Suprema de Belize assinalou o reconhecimento ao direito à terra dos povos indígenas bem como a reflexão dos princípios internacionais relativos aos $\operatorname{mesmos}^{67}$. E, no Brasil, o julgado federal da Seção Judiciária do Maranhão afirmou que o Estado não pode desconhecer a proteção constitucionalmente garantida como um dos objetivos fundamentais da República Federativa do Brasil, que busca promover o bem de todos, sem preconceitos de qualquer origem, conforme disposto no artigo $3^{\circ}$, IV da Constituição Federal.

Além disso, a Corte utilizou também como fundamento o Convênio 169 da OIT, que prevê a consulta prévia aos povos indígenas antes de efetuar qualquer procedimento em suas terras, e a Convenção de Viena da Organização das Nações Unidas - ONU.

Percebeu-se, ao estudar esse caso, que há um interconstitucionalismo inerente à segunda premissa explanada neste artigo, qual seja, referente à aplicação, por parte da Corte IDH, de norma constitucional de Estado diverso daquele que é parte no processo ao caso concreto. Isso porque o caso em comento versava sobre determinada comunidade indígena do Equador e como fundamentação para a sentença, a Corte utilizou-se de diversas normas constitucionais e jurisprudências de Supremas Cortes dos Estados da América Latina para solucionar a lide. Tudo isso para encontrar a legislação

INTERAMERICANA DE DIREITOS HUMANOS. CASO PUEBLO INDÍGENA KICHWA DE SARAYAKU VS. ECUADOR. SENTENCA DE 27 DE JUNHO DE 2012. Disponível em: $<$ http://www.corteidh.or.cr/docs/casos/articulos/seriec_245_esp. pdf>. Acesso em: 22 jun. 2015, p. 46.

66 Informações extraídas da sentença da Corte IDH. CORTE INTERAMERICANA DE DIREITOS HUMANOS. CASO PUEBLO INDÍGENA KICHWA DE SARAYAKU VS. ECUADOR. SENTENCA DE 27 DE JUNHO DE 2012. Disponível em: $<$ http://www.corteidh.or.cr/docs/casos/articulos/seriec_245_esp. pdf>. Acesso em: 22 jun. 2015, p. 46.

67 Corte Suprema de Belice, Aurelio Cal por derecho propio y en nombre de la Comunidad Maya de Santa Cruz y otros Vs. Procurador General de Belice y otros, casos 171 y 172 de 2007. Sentencia de 18 de octubre de 2007. Ver mais em: CORTE INTERAMERICANA DE DIREITOS HUMANOS. CASO PUEBLO INDÍGENA KICHWA DE SARAYAKU VS. ECUADOR. SENTENÇA DE 27 DE JUNHO DE 2012. Disponível em: <http://www.corteidh. or.cr/docs/casos/articulos/seriec_245_esp.pdf>. Acesso em: 22 jun. 2015, p. 47. mais protetiva com relação aos direitos da personalidade e aplicá-la ao caso concreto, propiciando, assim, maior efetividade aos direitos dos indivíduos.

\section{Considerações finais}

Preliminarmente, esta pesquisa objetivou estudar o fenômeno do interconstitucionalismo, surgido no âmbito europeu para, posteriormente, trazê-la para a realidade latino-americana. Assim, o problema principal deste artigo consistia em descobrir se existiriam perspectivas e albergue para o desenvolvimento de um interconstitucionalismo latino-americano e se ele, efetivamente, ocorria no âmbito da Corte Interamericana de Direitos Humanos, bem como se mostraria eficaz na tutela dos direitos da personalidade.

Apesar de este não ser tão aprimorado quanto o Sistema europeu, percebeu-se que haveria possibilidade de ocorrência do interconstitucionalismo o Sistema Interamericano de Direitos Humanos. Isso porque, uma vez que os Estados decidem fazer parte da Organização dos Estados Americanos, bem como tomam a decisão de ratificar a Convenção Americana de Direitos Humanos, fatalmente, se tornam parte em um sistema internacional. Assim, ficam subordinados a tais normas internacionais, e, dessa forma, fatalmente ocorrerá inter-relação entre ordens jurídicas, na medida em que, quando um caso é levado ao Sistema Interamericano, coexistirão e interagirão normas nacionais e internacionais.

Portanto, quedou-se claro neste artigo a possibilidade da ocorrência de interconstitucionalidade na América Latina. Para confirmar tal hipótese, a última parte do estudo visou constatar e comprovar a ocorrência do interconstitucionalismo no Sistema Interamericano de Direitos Humanos por meio da análise de um caso concreto.

Concluiu-se que a Comissão e a Corte Interamericana de Direitos Humanos utilizam-se do interconstitucionalismo dentro do Sistema Interamericano de Direitos Humanos. Isso porque, em suas decisões, percebe-se que é feito um estudo de direito comparado bastante minucioso e aprofundado nos ordenamentos jurídicos, que inclui as Cortes Supremas e as Constituições nacionais, bem como as normativas internacionais, como por exemplo, a Convenção Americana, com o intuito de buscar o fundamento mais apropriado e protetivo aos direitos da personalidade e aplicá-lo ao caso concreto. 
Assim, percebe-se que há um diálogo interconstitucional no Sistema Interamericano de Direitos Humanos. Portanto, ao final, após o estudo casuístico, verificou-se que o interconstitucionalismo mostrou-se como um meio eficaz para aprimoração e efetivação dos direitos da personalidade. Pode-se afirmar isso com base na seguinte justificativa: por meio do diálogo entre ordens jurídicas, é possível não somente observar os erros e acertos de cada sistema, mas também aprimorar e verificar quais normas e/ou jurisprudências são mais protetivas aos direitos da personalidade e aplicá-las ao caso concreto.

A grande inovação e aprimoramento na utilização dessa prática consiste no fato de que o interconstitucionalismo permite que os julgadores não fiquem restritos à aplicação da legislação do Sistema Interamericano de Direitos Humanos, apenas. Ao contrário, os julgadores da Comissão e da Corte IDH possuem certa liberdade para realizar pesquisa a fim de procurar em outras legislações constitucionais e jurisprudências de Cortes Superiores, a norma mais protetiva ao caso concreto e aplicá-las às lides, permitindo, assim, maior proteção e efetividade na tutela dos direitos humanos.

\section{REFERÊNCIAS}

aLVAREZ, Maria Luisa Ortiz. (Des) construção da identidade latino-americana: heranças do passado e desafios futuros. Disponível em: <http://unb.revistaintercambio.net. br/24h/pessoa/temp/anexo/1/231/427.pdf $>$. Acesso em: 16 jul. 2015.

CANOTILHO, J. J. Gomes. "Brancosos" e interconstitucionalidade: itinerários dos discursos sobre a historicidade constitucional. 2. ed. Almedina: Coimbra, 2008.

CONSTITUIÇÃO FEDERAL DA BOLÍVIA. Disponível em: <http://pdba.georgetown.edu/Constitutions/Bolivia/bolivia09.html>. Acesso em: 17 jun. 2015.

CONVENÇÃO AMERICANA SOBRE DIREITOS HUMANOS. Disponível em: <http://www.oas.org/ dil/esp/tratados_B-32_Convencion_Americana_sobre_Derechos_Humanos.htm>. Acesso em: 17 jun. 2015.

CORTE INTERAMERICANA DE DIREITOS HUMANOS. CASO PUEBLO INDÍGENA KICHWA
DE SARAYAKU VS. ECUADOR. SENTENCAA DE 27 DE JUNHO DE 2012. Disponível em: <http:// www.corteidh.or.cr/docs/casos/articulos/seriec_245_ esp.pdf>. Acesso em: 22 jun. 2015.

DELMAS-MARTY, Mireille. Les forces imaginantes du droit: le relaatif et l'universel. Paris, França: Seuil, 2004.

DUARTE, Écio Oto Ramos. Entre constitucionalismo cosmopolita e pluriversalismo internacional: neoconstitucionalismo e ordem mundial. Rio de Janeiro: Lumen Juris, 2014.

ENGELMANN, Wilson. A crise constitucional: a linguagem e os direitos humanos como condição de possibilidade para preservar o papel da Constituição no mundo globalizado. In: MORAIS, José Luis Bolzan de (Org.) O Estado e suas crises. Porto Alegre: Livraria do Advogado, 2005.

FERRAJOLI, Luigi. A soberania no mundo moderno: nascimento e crise do Estado nacional. Tradução de Carlo Coccioli e Márcio Lauria Filho. Revisão da tradução de Karina Jannini. 2. ed. São Paulo: Martins Fontes, 2007.

- Democracia, estado de direito e jurisdição na crise do estadonacional.Disponívelem: < file:///D:/PC\%20Malu/ Pessoal/Mestrado/Disserta\%C3\%A7\%C3\%A3o/ FERRAJOLI\%20DIREITO \%20DO \%20ESTADO\%202013.pdf>. Acesso em: 03 jun. 2015.

FLEURI, Reinaldo Matias. In Palestra Proferida no V Colóquio Internacional Paulo Freire - 2005. Disponível em: <www.paulofreire.org.br/Textos/ fleuri_2005_recife_resumo_e_texto_completo.pdf $>$. Acesso em: 06 jun. 2015.

GIDDENS, Anthony. A terceira via: reflexões sobre o impasse político atual e o futuro da sociela-democracia. Tradução de Maria Luiza X. de A. Borges. Rio de Janeiro: Record, 2000.

HÄBERLE, Peter. Estado constitucional cooperativo. Rio de Janeiro: Renovar, 2007.

; HABERMAS; Jürgen; FERRAJOLI, Luigi. VITALE, Ermanno. La constitucionalización de Europa. México: Instituto de Investigaciones Jurídicas de la UNAM, 2004.

LEAL, Mônia Clarissa Hennig. La noción de constitución abierta de peter haberle como fundamento de una jurisdicción constitucional abierta y como presupuesto para la intervención del amicus curiae en el derecho brasileño. In: Estudios Constitucionales, Año 8, No 1, 2010, pp. 283 - 304. 
LUHMANN, Niklas. A constituição como Aquisição Evolutiva. Tradução realizada a partir do original ("Verfassung als evolutionäre Errungenschaft”. In: Rechthistorisches Journal. Vol. IX, 1990, pp. 176 a 220), cotejada com a tradução italiana de F. Fiore ("La costituzione come acquisizione evolutiva". In: ZAGREBELSKY, Gustavo. PORTINARO, Pier Paolo. LUTHER, Jörg. Il Futuro della Costituzione. Torino: Einaudi, 1996), por Menelick de Carvalho Netto, Giancarlo Corsi e Raffaele De Giorgi. Notas de rodapé traduzidas da versão em italiano por Paulo Sávio Peixoto Maia (texto não revisado pelo tradutor), p. 04.

NEVES, Marcelo. Transconstitucionalismo. São Paulo: Martins Fontes, 2013.

PIOVESAN, Flavia. Direitos humanos e diálogo entre jurisdições. In: Revista Brasileira de Direito ConstitucionalRBDC, n. 19, p. 67-93, jan-jun, 2012.
Direitos humanos e justiça internacional: um estudo comparativo dos sistemas regionais europeu, interamericano e africano. $2^{a}$ ed. São Paulo: Saraiva, 2011.

SEIXAS, Renato. Identidade Cultural da América Latina: conflitos culturais globais e mediaģão simbólica. Disponível em: <http://www.usp.br/prolam/downloads/2008_1_4. pdf>. Acesso dia: 16/07/2015, p. 98.

VASCONCELOS, Luciana Machado de. Interculturalidade. Disponível em: < http://www.cult.ufba.br/maisdefinicoes/INTERCULTURALIDADE.pdf $>$. Acesso em: 08 jun. 2015.

WOLKMER, Antonio Carlos. Pluralismo crítico e perspectivas para um novo constitucionalismo na América Latina. In: WOLKMER, Antonio Carlos; MELO, Milena Petters. (Orgs.). Constitucionalismo latino-americano: tendências contemporâneas. Curitiba: Juruá, 2013. 
Para publicar na Revista de Direito Internacional, acesse o endereço eletrônico www.rdi.uniceub.br ou www.brazilianjournal.org.

Observe as normas de publicação, para facilitar e agilizar o trabalho de edição. 